\title{
BIO_16 - Alternative in vitro method for potency evaluation of recombinant human erythropoietin
}

Thaysa Válega de Oliveira Faria ${ }^{1}$; Fernando de Paiva Conte ${ }^{1}$; Alessandra Santos Almeida ${ }^{1}$; Daniel da Silva Guedes Junior ${ }^{1}$; Katherine Antunes de Mattos ${ }^{1}$.

${ }^{1}$ Fiocruz/Bio-Manguinhos.

Introduction: The recombinant human erythropoietin (rHuEPO) is widely used to treat anemia in patients with chronic renal failure, in phase of dialysis or pre-dialysis, systolic heart failure, cancer and HIV. Currently, the biological potency of alphaepoetin produced by Bio-Manguinhos/Fiocruz is evaluated through the assay in normocythemic mice and reticulocyte count in a Neubauer chamber, as recommended by the European Pharmacopoeia (EP). In line with the world trend of decreasing the use of animals (3 R's Replacement, Reduction and Refinement) and an optimization of potency tests, the possibility of using the alternative bioassay based on assessing cell proliferation was evaluated using the leukemic erythroid cell line, TF-1, which depends on erythropoietin as hematopoietic factor. This test is a promising alternative that is easy to perform, lower cost and faster results and can be implemented in routine quality control.

Objective: To evaluate the biological potency of rHuEPO, through the in vitro cell proliferation method by MTT (methyltiazole tetrazolium assay) using the TF-1 cell line, as an alternative to the In vivo method that uses normocythemic mice and reticulocyte count.

Methodology: The TF-1 cell (ECACC) was seeded in a 96-well plate and stimulated with differents presentations rHuEPO: BRP (international reference material, EP), MRT (QFB) rhEPO (working reference material) and alfaepoetina ${ }^{\circledR}$ (biopharmaceutical produced by Bio-Manguinhos) and incubated $37{ }^{\circ} \mathrm{C}$ during $48 \mathrm{~h}$. The influence of $\mathrm{rHuEPO}$ on cell proliferation was assessed by MTT. To ensure the accuracy and validity of the test, preparatory tests were conducted in different concentrations and geometric ratios from serial dilutions of 0.1 to $12.8 \mathrm{IU} / \mathrm{mL}$ to determine the dose-response curve, as criteria described in EP.

Results: The different presentations of $\mathrm{rHuEPO}$ induced more than $100 \%$ proliferation with the $2.0 \mathrm{IU} / \mathrm{mL}$ stimulus, both when stimulated with epoetin alfa (MRT and alfaepoetina $\left.{ }^{\circledR}\right)$ or alfa and beta epoetin (BRP). Human albumin used as stabilizer in alfaepoetin ${ }^{\circledR}$ formulations, can be a potential interferer, however did not affect cell proliferation, inducing more than $100 \%$ compared to control without stimulation. The results of the curve demonstrated that the points suitable for linearity would be $0.1-1.6 \mathrm{IU} / \mathrm{mL}$, with $\mathrm{R}^{2}>9.7$ and significance of the regression $\mathrm{p}<0.05$. The analysis of BRP, MRT and alfaepoetina ${ }^{\circledR}$ showed a curve regression with significant values.

Conclusion: The analysis indicate the potential of the technique in the possible replacement of the current in vivo method by the in vitro cell proliferation assay, which still deserves methodological adjustments. The project opens up an avenue of opportunities given the international recruitment of efforts to reduce animals, initiating a preventive mission to the future regulations regarding the use of animals in Brazil.

Keywords: Erythropoietin; alternative method; quality control 